\title{
Management and treatment of contact lens-related Pseudomonas keratitis
}

This article was published in the following Dove Press journal:

Clinical Ophthalmology

16 June 2012

Number of times this article has been viewed

\section{Mark DP Willcox}

School of Optometry and Vision Science, University of New South Wales, Sydney, Australia
Correspondence: Mark DP Willcox

School of Optometry and Vision Science, University of New South Wales, Sydney, NSW 204I, Australia

Tel +6I 293854 I 64

Fax +6I $293 \mid 36243$

Emailmdpwillcox@gmail.com
Abstract: Pubmed and Medline were searched for articles referring to Pseudomonas keratitis between the years 2007 and 2012 to obtain an overview of the current state of this disease. Keyword searches used the terms "Pseudomonas" + "Keratitis" limit to "2007-2012", and ["Ulcerative" or "Microbial"] + "Keratitis" + "Contact lenses" limit to "2007-2012". These articles were then reviewed for information on the percentage of microbial keratitis cases associated with contact lens wear, the frequency of Pseudomonas sp. as a causative agent of microbial keratitis around the world, the most common therapies to treat Pseudomonas keratitis, and the sensitivity of isolates of Pseudomonas to commonly prescribed antibiotics. The percentage of microbial keratitis associated with contact lens wear ranged from $0 \%$ in a study from Nepal to $54.5 \%$ from Japan. These differences may be due in part to different frequencies of contact lens wear. The frequency of Pseudomonas sp. as a causative agent of keratitis ranged from $1 \%$ in Japan to over $50 \%$ in studies from India, Malaysia, and Thailand. The most commonly reported agents used to treat Pseudomonas keratitis were either aminoglycoside (usually gentamicin) fortified with a cephalosporin, or monotherapy with a fluoroquinolone (usually ciprofloxacin). In most geographical areas, most strains of Pseudomonas sp. ( $\geq 95 \%)$ were sensitive to ciprofloxacin, but reports from India, Nigeria, and Thailand reported sensitivity to this antibiotic and similar fluoroquinolones of between $76 \%$ and $90 \%$.

Keywords: Pseudomonas, keratitis, contact lens

\section{Introduction}

Microbial keratitis (MK), epithelial loss from the cornea with underlying stromal infiltration by white blood cells and disintegration of the stroma, occurs when one of the protective mechanisms of the ocular surface is disrupted. It is a vision-threatening condition that requires rapid and appropriate management and antibiotic treatment if vision loss is to be prevented. MK caused by Pseudomonas aeruginosa is commonly associated with contact lens wear (Table 1) ${ }^{1-21}$ Predisposing risk factors for microbial keratitis can vary with geographical location and can depend on the penetration of contact lens wear. The differences may also be associated with the incidence of single nucleotide polymorphisms (SNPs) in cytokine genes in different populations. Recently, SNPs in the gene for interleukin (IL)-10 have been associated with severity of and predisposition to MK. ${ }^{22}$ In developing countries, trauma to the eye may be a predominant risk factor, ${ }^{23}$ whereas in developed countries, contact lens wear is often the most important risk factor. ${ }^{24} \mathrm{~A}$ study from Malaysia suggested that as $P$. aeruginosa is also a common inhabitant of soil, water, and vegetation, it may also be the main pathogen following vegetation-related corneal injury in certain regions. ${ }^{15}$ 
Table I Percent of microbial keratitis cases associated with contact lens wear

\begin{tabular}{|c|c|c|}
\hline $\begin{array}{l}\text { Geographical } \\
\text { location }\end{array}$ & Country & $\begin{array}{l}\% \text { MK associated with } \\
\text { contact lens wear }\end{array}$ \\
\hline \multirow[t]{2}{*}{ North America } & USA' & 55 \\
\hline & USA $^{2}$ & 26.5 \\
\hline South America & Brazil $^{3}$ & 12.8 \\
\hline \multirow[t]{7}{*}{ Europe } & $\mathrm{UK}^{4}$ & 31 \\
\hline & $\mathrm{UK}^{5}$ & 32 \\
\hline & $\mathrm{UK}^{6}$ & 30.3 \\
\hline & Ireland ${ }^{7}$ & 41.1 \\
\hline & The Netherlands ${ }^{8}$ & 39.7 \\
\hline & Turkey 9 & 3.2 \\
\hline & Italy 10 & 46.1 \\
\hline \multirow[t]{2}{*}{ Indian subcontinent } & India"I & 17.14 \\
\hline & India ${ }^{12}$ & 8.2 \\
\hline \multirow[t]{5}{*}{ Asia } & Japan ${ }^{13}$ & 54.5 \\
\hline & $\mathrm{Nepal}^{14}$ & 0 \\
\hline & Malaysia $^{15}$ & 21 \\
\hline & Thailand ${ }^{16}$ & 18.6 \\
\hline & Thailand ${ }^{17}$ & 32.4 \\
\hline \multirow[t]{3}{*}{ Australasia } & New Zealand ${ }^{19}$ & 29.4 \\
\hline & Australia ${ }^{20}$ & 21.7 \\
\hline & Australia $^{21}$ & 21 \\
\hline
\end{tabular}

The incidence of contact lens-related microbial keratitis has been estimated over the past 20 years, and has remained almost constant at 1/2500 contact lens wearers who wear lenses on a daily wear basis (that is removing lenses each night and placing in disinfecting solution prior to re-wearing the lens the next day), or 1/500 wearers if the lenses are worn on a continuous or extended wear basis (ie, the person wears lenses for 24 hours, sleeping in lenses overnight). ${ }^{25}$ It is now common for lens wearers to discard their lenses after 2 weeks or 1 month of wear. ${ }^{25}$ In a study from North America, it was found that the incidence of all ulcerative keratitis was 2.76 per 10,000 person-years ( $95 \%$ confidence interval [CI]: 2.46-3.09) but the incidence of contact lens-associated keratitis was 13.04 per 10,000 person-years (95\% CI: $11.13-15.17)$, with an adjusted relative risk of $9.31(7.42-11.7 ; P<0.001)$ compared with non-contact lens wearers. ${ }^{1}$ Another study put the incidence of MK at 1.1 per 10,000 persons/year in the $\mathrm{US}^{24}$ but a different study found an incidence of 79.9 per 10,000 persons/ year in Nepal. ${ }^{23}$ The risk with therapeutic contact lenses is higher at approximately 52/10,000 yearly. ${ }^{26} \mathrm{~A}$ study of armed forces of the UK evacuated because of keratitis from the Middle East showed an incidence of MK of 35 per 10,000 (with 74\% being associated with soft contact lens wear). ${ }^{27}$

The percentage of microbial keratitis cases caused by Pseudomonas species (most likely P. aeruginosa) is shown in Table 2 for different geographical locations. ${ }^{1-13,15-18,28-44}$ Whilst
Table 2 Frequency of Pseudomonas sp. as a causative agent of microbial keratitis in different geographical regions

\begin{tabular}{|c|c|c|}
\hline $\begin{array}{l}\text { Geographical } \\
\text { region }\end{array}$ & Country & $\begin{array}{l}\text { Frequency (\%) } \\
\text { of Pseudomonas sp. } \\
\text { as a total of all MK isolates }\end{array}$ \\
\hline \multirow[t]{2}{*}{ North America } & USA $^{\prime}$ & 0 \\
\hline & USA $^{2}$ & 20.2 \\
\hline \multirow[t]{2}{*}{ South America } & Brazil $^{3}$ & 12 \\
\hline & Brazil $^{28}$ & $\begin{array}{l}\text { I2 ( } 41 \% \text { of these caused by } \\
\text { P. aeruginosa) }\end{array}$ \\
\hline \multirow[t]{9}{*}{ Europe } & $\mathrm{UK}^{29}$ & 6 (1995-1998); 15 (2004-2007) \\
\hline & $\mathrm{UK}^{4}$ & 12 \\
\hline & $\mathrm{UK}^{5}$ & 21 \\
\hline & $\mathrm{UK}^{6}$ & $\begin{array}{l}28.5 \text { ( } 24.3 \% \text { of total cases } \\
\text { caused by } P \text {. aeruginosa) }\end{array}$ \\
\hline & $\mathrm{UK}^{30}$ & 20.9 \\
\hline & Ireland ${ }^{7}$ & 33.3 (56.2 of CLMK) \\
\hline & The Netherlands ${ }^{8}$ & 22.4 \\
\hline & Turkey ${ }^{9}$ & 6.6 (Pseudomonas sp.) \\
\hline & Italy $10^{\prime}$ & 72.2 \\
\hline \multirow[t]{7}{*}{ Middle East } & Iraq & $\begin{array}{l}42(100 \% \text { of those associated } \\
\text { with contact lenses caused } \\
\text { by Pseudomonas sp.) }\end{array}$ \\
\hline & Kingdom & $54(95 \%$ of those associated \\
\hline & of Bahrain ${ }^{32}$ & $\begin{array}{l}\text { with contact lenses caused } \\
\text { by } P \text {. aeruginosa) }\end{array}$ \\
\hline & Various ${ }^{27}$ & 71 \\
\hline & (predominantly & \\
\hline & Iraq) & \\
\hline & Oman & 28.8 (all CLMK) \\
\hline \multirow[t]{2}{*}{ Africa } & Sierra Leone ${ }^{34}$ & 40 \\
\hline & Nigeria $^{35}$ & 22.4 \\
\hline \multirow{5}{*}{$\begin{array}{l}\text { Indian } \\
\text { subcontinent }\end{array}$} & India ${ }^{36}$ & 7I (only cases of CLMK \\
\hline & & $\begin{array}{l}\text { examined, all Pseudomonas } \\
\text { species were } P \text {. aeruginosa) }\end{array}$ \\
\hline & India ${ }^{37}$ & 52 \\
\hline & India"I & 1 \\
\hline & India ${ }^{12}$ & 24.4 \\
\hline \multirow[t]{10}{*}{ Asia } & $\mathrm{Japan}^{38}$ & 2.8 \\
\hline & Japan ${ }^{18}$ & 20 \\
\hline & $J_{a p a n}^{13}$ & 1 \\
\hline & Thailand ${ }^{16}$ & 59 \\
\hline & Thailand ${ }^{17}$ & 55 \\
\hline & Malaysia ${ }^{15}$ & 58.6 \\
\hline & Hong Kong ${ }^{39}$ & 42.9 (85.7 of culture proven) \\
\hline & & for CLMK \\
\hline & China $^{40}$ & 20.07 \\
\hline & Taiwan $^{4 l}$ & 47 \\
\hline \multirow[t]{5}{*}{ Australasia } & New Zealand ${ }^{42}$ & 3.4 (all P. aeruginosa) \\
\hline & Australia $^{43}$ & 8 \\
\hline & Australia $^{21}$ & I $755 \%$ of these caused \\
\hline & & by $P$. aeruginosa) \\
\hline & Australia $^{44}$ & 35 (CLMK; 49.2 of culture \\
\hline
\end{tabular}

P. aeruginosa/Pseudomonas $\mathrm{sp}$. are usually a predominant causative agent, temperate zones tend to have a higher incidence of Gram-positive bacteria causing the disease and less aggressive keratitis. ${ }^{44}$ In most studies, Pseudomonas sp. are usually isolated in monoculture from cases of MK, however, a study 
from Thailand demonstrated that in $46 \%$ of MK cases caused by Pseudomonas sp. other Gram-negative bacteria including Escherichia coli, Acinetobacter calcoaceticus, Klebsiella pneumoniae, Serratia marcescens, and Enterobacter sp. could also be cultured. ${ }^{16}$ However, the predominance of $P$. aeruginosa during contact lens-associated MK is not always seen. For example, even though $29.4 \%$ of MK cases were associated with contact lens wear in a study from Wellington, New Zealand, no cultures of $P$. aeruginosa were reported. ${ }^{19}$ The predominant Gram-negative bacteria isolated was Moraxella sp. (12.5\% of all bacterial isolates), ${ }^{19}$ and this predominance of Moraxella sp. from MK scrapes has been reported from a study in Christchurch, New Zealand. ${ }^{45}$ Climate may also affect the incidence of $P$. aeruginosa keratitis. In Australia, the incidence of $P$. aeruginosa contact lens microbial keratitis (CLMK) is increased in tropical compared to temperate zones, whereas the incidence of Serratia marcescens CLMK is higher in temperate zones. ${ }^{44}$

Determinants of the clinical outcome of $\mathrm{MK}$ include distance of the ulcer from the limbus and the minimum inhibitory concentration (MIC) of the first antimicrobial used or lowest MIC if combination therapy was used. ${ }^{5}$ A large multicenter clinical trial with participants from India and the US has shown that $P$. aeruginosa ulcers were significantly worse for visual acuity than patients with other bacterial ulcers, but interestingly showed significantly more improvement in 3-month best-spectacle-corrected visual acuity than those with other bacterial ulcers. ${ }^{46}$ Pseudomonas $\mathrm{sp}$. are often associated with the largest ulcers. ${ }^{5}$

Ideally, every case of presumed MK should be scraped for microbiological investigations, especially with the possibility of increasing isolation of antibiotic-resistant microbes. However, it must be borne in mind that there is often a small ulcer and so relatively little material might be obtained. Corneal scrapings obtained with a surgical blade (eg, BardParker blade \#15), Kimura spatula, or 21-gauge disposable needle should be inoculated on chocolate agar, sheep blood agar, and into thioglycolate broth, and incubated at $35^{\circ} \mathrm{C}$. Sabouraud's agar plates should also be used and these are maintained at $25^{\circ} \mathrm{C}$ to enhance fungal growth. Samples may also be inoculated onto non-nutrient agar and into brain heart infusion broth. Scraping of small lesions (smaller than $2.0 \mathrm{~mm}^{2}$ ) is probably not worthwhile, and patients with such lesions can be empirically treated. Scrapes should not only be sent for microbial culture, but also smeared onto microscope slides and examined by Gram stain (and potassium hydroxide if fungal keratitis is suspected). However, as there is often only a small amount of material, cultures on agar plates for bacteria and fungi, as well as Gram stain, are most often used. The following clinical parameters are useful in monitoring the clinical response to antibiotic therapy: blunting of the perimeter of the stromal infiltrate, decreased density of the stromal infiltrate, reduction of stromal edema and endothelial inflammatory plaque, reduction in anterior chamber inflammation, re-epithelialization, and cessation of corneal thinning.

Therapies used in different geographical locations are shown in Table 3.,5,8,9,12,16,31,39,42,47-49 Monotherapy with ciprofloxacin $(0.3 \%$; or another fluoroquinolone) is commonly used. In severe cases, subconjunctival injections of gentamicin may be used. ${ }^{31}$ The combination of two fortified antibiotic preparations, $1.5 \%$ gentamicin and 5\% cefuroxime, covers almost the entire range of common bacterial pathogens causing

Table 3 Most common topical antimicrobial therapies used to treat Pseudomonas keratitis by geographical location

\begin{tabular}{|c|c|c|}
\hline $\begin{array}{l}\text { Geographical } \\
\text { region }\end{array}$ & Country & $\begin{array}{l}\text { Antibiotics commonly } \\
\text { prescribed }\end{array}$ \\
\hline \multirow[t]{4}{*}{ Europe } & The Netherlands ${ }^{8}$ & $\begin{array}{l}\text { Cefazolin and tobramycin/ } \\
\text { gentamicin; ofloxacin } \\
\text { monotherapy }\end{array}$ \\
\hline & Ireland ${ }^{9}$ & $\begin{array}{l}\text { Ceftazidime and vancomycin; } \\
\text { ofloxacin }\end{array}$ \\
\hline & UK $^{4}$ & Ciprofloxacin \\
\hline & $\mathrm{UK}^{5}$ & $\begin{array}{l}\text { Ciprofloxacin or ofloxacin } \\
\text { (84\% monotherapy; } \\
9 \% \text { combination therapy) }\end{array}$ \\
\hline \multirow[t]{2}{*}{ Middle East } & $\operatorname{Iraq}^{31}$ & Ciprofloxacin \\
\hline & $\operatorname{Iran}^{47}$ & $\begin{array}{l}\text { Fortified ceftazidime and } \\
\text { vancomycin; ciprofloxacin } \\
\text { for small }(<2 \mathrm{~mm}) \text { ulcers }\end{array}$ \\
\hline $\begin{array}{l}\text { Indian } \\
\text { subcontinent }\end{array}$ & India $^{12}$ & $\begin{array}{l}\text { Fortified cefazolin; tobramycin } \\
\text { (modified depending on } \\
\text { sensitivity analysis and clinical } \\
\text { response) }\end{array}$ \\
\hline \multirow[t]{2}{*}{ Asia } & Hong Kong ${ }^{39}$ & $\begin{array}{l}\text { Levofloxacin or gentamicin } \\
\text { monotherapy; fortified } \\
\text { gentamicin }\end{array}$ \\
\hline & Thailand $d^{16}$ & $\begin{array}{l}\text { Fortified antibiotics (gentamicin } \\
\text { or amikacin or ceftazidime } \\
\text { and/or cefazolin); ciprofloxacin } \\
\text { and/or tobramycin }\end{array}$ \\
\hline \multirow[t]{3}{*}{ Australasia } & New Zealand $d^{48}$ & $\begin{array}{l}\text { Severe cases fortified } \\
\text { gentamicin or Tobramycin; } \\
\text { ciprofloxacin; mild cases } \\
\text { ciprofloxacin; chloramphenicol }\end{array}$ \\
\hline & New Zealand $d^{42}$ & $\begin{array}{l}\text { Fortified cefuroxime and } \\
\text { tobramycin; ciprofloxacin in } \\
\text { cases where scrape results } \\
\text { show Gram-negative organisms } \\
\text { resistant to tobramycin }\end{array}$ \\
\hline & Australia ${ }^{49}$ & $\begin{array}{l}\text { Fluoroquinolone monotherapy; } \\
\text { ceftazidime/gentamicin }\end{array}$ \\
\hline
\end{tabular}


corneal ulcers. Randomized controlled trials have demonstrated that monotherapy with fluoroquinolones has non-inferiority and fewer side effects compared with combination therapy. ${ }^{50,51}$ A study from Iran recommended the concurrent use of ceftazidime and amikacin or ceftazidime and ciprofloxacin as the initial treatment based on antibiotic sensitivities of isolates, and as all $P$. aeruginosa isolates were resistant to chloramphenicol, trimethoprim, vancomycin, and cefazolin, these antibiotics should probably not be included in any empirical antibiotic regimen in that country. ${ }^{47}$ Data from Taiwan ${ }^{41}$ demonstrate that ciprofloxacin was statistically significantly more effective against $P$. aeruginosa than the combination of cefazolin and gentamicin. Whilst therapy is most often, if not always, commenced prior to results of cultures being obtained, a study from Japan has shown that the therapeutic outcome was better when antimicrobial agents were selected based on culture results, thus reemphasizing the importance of culture studies. ${ }^{18}$
Sometimes a combination of piperacillin/tazobactam might be effective with unresponsive $P$. aeruginosa MK. ${ }^{52}$

The use of steroids in conjunction with antibiotics has been a source of controversy for many years, despite the demonstration in an animal trial that the combination of tobramycin and dexamethasone was safe and resulted in the reduction of clinical scores and lower bacterial numbers in the cornea. ${ }^{53}$ However, a recent large scale multicenter clinical trial that enrolled subjects in India and US found that the use of moxifloxacin combined with prednisolone phosphate did not improve overall clinical outcome. ${ }^{46}$

Sensitivity of Pseudomonas sp. to antibiotics by geographical region is shown in Table 4. 2,7,8,16,20,21,28-31,35,37,40-42,47,54 Generally $P$. aeruginosa is sensitive to fluoroquinolones, but there have been reports of multi-resistant $P$. aeruginosa strains, for example, from Australia where the strains were resistant to ciprofloxacin, gentamicin, tobramycin,

Table 4 Sensitivity to antibiotics of Pseudomonas sp. in different geographical regions

\begin{tabular}{|c|c|c|c|c|c|c|}
\hline \multirow{2}{*}{$\begin{array}{l}\text { Pseudomonas } \\
\text { type }\end{array}$} & \multirow[t]{2}{*}{ Country } & \multicolumn{5}{|c|}{ Percentage of strains sensitive to antibiotic } \\
\hline & & Ciprofloxacin & Gentamicin & Cephalosporin & Tobramycin & Chloramphenicol \\
\hline P. aeruginosa & USA $^{2}$ & $100($ levofloxacin $=100)$ & $93.7^{\mathrm{a}}$ & ND & $93.7^{\mathrm{a}}$ & ND \\
\hline P. aeruginosa & Brazil $^{28}$ & $\begin{array}{l}100(\text { ofloxacin = } 100 \\
\text { gatifloxacin }=100)\end{array}$ & 97 & ND & 100 & ND \\
\hline Pseudomonas sp. & Brazil $^{54}$ & $\begin{array}{l}95(\text { ofloxacin }=95 \\
\text { gatifloxacin }=95)\end{array}$ & ND & ND & ND & ND \\
\hline Pseudomonas sp. & Ireland ${ }^{7}$ & $100($ ofloxacin $=100)$ & 100 & $\begin{array}{l}73 \text { (cefotaxime); } \\
100 \text { (ceftazidime); } \\
\text { I8 (cefuroxime) }\end{array}$ & ND & ND \\
\hline P. aeruginosa & $\mathrm{UK}^{30}$ & $\begin{array}{l}98.6(\text { levofloxacin }=99.3 ; \\
\text { moxifloxacin }=100)\end{array}$ & 96.4 & 99.3 (ceftazidime) & ND & ND \\
\hline Pseudomonas sp. & $\mathrm{UK}^{29}$ & 100 & 100 & $\begin{array}{l}100 \text { (1995-1998); } \\
0 \text { (2004-2007) } \\
\text { (cefuroxime) }\end{array}$ & ND & ND \\
\hline P. aeruginosa & The Netherlands ${ }^{8}$ & 100 & ND & ND & ND & ND \\
\hline Pseudomonas sp. & $\operatorname{Iraq}^{31}$ & 62 & 55 & 2 (cefazolin) & ND & 0 \\
\hline P. aeruginosa & $\operatorname{Iran}^{47}$ & 100 & 93 & $\begin{array}{l}0 \text { (cefalozin); } \\
100 \text { (ceftazidime) }\end{array}$ & ND & 3 \\
\hline P. aeruginosa & India $^{37}$ & $\begin{array}{l}85 \text { (norfloxacin }=82 \\
\text { ofloxacin = 87; } \\
\text { gatifloxacin = 88; } \\
\text { moxifloxacin }=79)\end{array}$ & 33 & $\begin{array}{l}0 \text { (cefalozin); } \\
64 \text { (cephotaxime); } \\
80 \text { (cetazidime) }\end{array}$ & 30 & 60 \\
\hline P. aeruginosa & Nigeria $^{35, b}$ & $90($ ofloxacin $=80)$ & 90 & 20 (cephalexin) & ND & 10 \\
\hline P. aeruginosa & Taiwan $^{41}$ & 99 & 91 & 99 (ceftazidime) & ND & ND \\
\hline P. aeruginosa & Thailand $d^{16}$ & 100 (data for ofloxacin) & 100 & 100 (ceftazidime) & ND & ND \\
\hline Pseudomonas sp. & China $^{40}$ & $\begin{array}{l}76(\text { ofloxacin }=89 \\
\text { levofloxacin }=96)\end{array}$ & ND & ND & 87 & ND \\
\hline P. aeruginosa & New Zealand ${ }^{42}$ & $99 c$ & ND & 99.7 (cefuroxime) & 100 & ND \\
\hline P. aeruginosa & Australia ${ }^{20}$ & 100 & 100 & ND & ND & 100 \\
\hline P. aeruginosa & Australia $^{21}$ & 100 & 100 & $\begin{array}{l}100 \text { (ceftazidime or } \\
\text { cefotaxime) }\end{array}$ & ND & ND \\
\hline
\end{tabular}

Notes: ${ }^{a}$ Data supplied as 'intermediate or resistant to gentamicin or tobramycin'; ball ocular infections not just MK; 'data supplied for all Gram-negative microbes combined.

Abbreviations: MK, microbial keratitis; ND, not given or determined. 
and amikacin but was sensitive to ceftazidime, imipenem, meropenem, and timentin. ${ }^{55}$ Recent data examining possible synergistic activity between different classes of antibiotics against $P$. aeruginosa has shown that a combination of meropenem/ciprofloxacin gave the lowest mean fractional inhibitory concentrations (ie, best synergy) for P. aeruginosa isolates, with $90 \%$ of isolates showing an additive or synergistic effect ${ }^{56}$ and so this may be a promising therapy for the more resistant strains.

Comparisons between Tables 3 and 4 demonstrate that ciprofloxacin is the most commonly prescribed antibiotic to treat MK in Iraq, however only $62 \%$ of Pseudomonas sp. are sensitive to it. Likewise for India, tobramycin is one of the most commonly prescribed antibiotics but only $30 \%$ of Pseudomonas sp. are sensitive to it. This is different from all other most commonly prescribed treatments in other geographical locations which are $>95 \%$ effective. Whilst there are no true cut-off points for sensitivity or resistance for topically applied antibiotics, it is perhaps important for those countries where there are high levels of apparently resistant strains of $P$. aeruginosa to monitor the clinical outcome of MK very carefully.

In conclusion, Pseudomonas sp. (predominantly P. aeruginosa) is often isolated from cases of contact lensinduced microbial keratitis. The most commonly used therapies to treat this disease are either monotherapy with a fluoroquinolone or fortified aminoglycosides. Strains of $P$. aeruginosa isolated from contact lens-induced MK are commonly still sensitive to these antibiotics, but geographic differences in sensitivity exist and should be taken into account when recommending treatment options.

\section{Disclosure}

The author reports no conflicts of interest in this work.

\section{References}

1. Jeng BH, Gritz DC, Kumar AB, et al. Epidemiology of ulcerative keratitis in northern California. Arch Ophthalmol. 2010;128:1022-1028.

2. Pachigolla G, Blomquist P, Cavanagh HD. Microbial keratitis pathogens and antibiotic susceptibilities: a 5-year review of cases at an urban county hospital in north Texas. Eye Contact Lens. 2007;33:45-49.

3. Cariello AG, Passos RM, Yu MC, Hofling-Lima AL. Microbial keratitis at a referral center in Brazil. Int Ophthalmol. 2011;31:197-204.

4. Ibrahim YW, Boase DL, CreeI IA. Epidemiological characteristics, predisposing factors and microbiological profiles of infectious corneal ulcers: the Portsmouth corneal ulcer study. Br J Ophthalmol. 2009;93:1319-1324.

5. Kaye S, Tuft S, Neal T, et al. Bacterial susceptibility to topical antimicrobials and clinical outcome in bacterial keratitis. Invest Ophthalmol Vis Sci. 2010;51:362-368.

6. Orlans HO, Hornby SJ, Bowler IC. In vitro antibiotic susceptibility patterns of bacterial keratitis isolates in Oxford, UK: a 10-year review. Eye. 2011;25:489-493.
7. Saeed A, D' Arcy F, Stack J, Collum LM, Power W, Beatty S. Risk factors, microbiological findings, and clinical outcomes in cases of microbial keratitis admitted to a tertiary referral center in Ireland. Cornea. 2009;28:285-292.

8. van der Meulen IJ, van Rooij J, Nieuwendaal CP, Cleijnenbreugel HV, Geerards AJ, Remeijer L. Age-related risk factors, culture outcomes, and prognosis in patients admitted with infectious keratitis to two Dutch tertiary referral centers. Cornea. 2008;27:539-544.

9. Yilmaz S, Ozturk I, Maden A. Microbial keratitis in West Anatolia, Turkey: a retrospective review. Int Ophthalmol. 2007;27:261-268.

10. Cruciani F, Cuozzo G, Di Pillo S, Cavallaro M. Predisposing factors, clinical and microbiological aspects of bacterial keratitis: a clinical study. Clin Ter. 2009;160:207-210.

11. Kumar A, Pandya S, Kavathia G, Antala S, Madan M, Javdekar T. Microbial keratitis in Gujarat, Western India: findings from 200 cases. Pan Afr Med J. 2011;10:48-56.

12. Panda A, Satpathy G, Nayak N, Kumar S, Kumar A. Demographic pattern, predisposing factors and management of ulcerative keratitis: evaluation of one thousand unilateral cases at a tertiary care centre. Clin Experiment Ophthalmol. 2007;35:44-50.

13. Toshida H, Kogure N, Inoue N, Murakami A. Trends in microbial keratitis in Japan. Eye Contact Lens. 2007;33;70-73.

14. Lavaju P, Arya SK, Khanal B, Amatya R2, Patel S. Demographic pattern, clinical features and treatment outcome of patients with infective keratitis in the eastern region of Nepal. Nepal J Ophthalmol. 2009;1:101-106.

15. Norina TJ, Raihan S, Bakiah S, Ezanee M, Liza-Sharmini AT, Wan Hazzabah WH. Microbial keratitis: aetiological diagnosis and clinical features in patients admitted to Hospital Universiti Sains Malaysia. Singapore Med J. 2008;49:67-71.

16. Preechawat $P$, Ratananikom U, Lerdvitayasakul R, Kunavisarut S. Contact lens-related microbial keratitis. J Med Assoc Thai. 2007;90:737-743.

17. Sirikul T, Prabriputaloong T, Smathivat A, Chuck RS, Vongthongsri A. Predisposing factors and etiologic diagnosis of ulcerative keratitis. Cornea. 2008;27:283-287.

18. Uno T, Fukuda M, Ohashi Y, et al. Survey of severe contact lens associated microbial keratitis in Japan. Nihon Ganka Gakkai Zasshi. 2011;115:107-115.

19. Rajpal K, Hall R, Long H, Wells A. Five-year experience of corneal scrapes at Wellington Eye Department, New Zealand. $N Z$ Med J. 2007;120(1260):U2682.

20. Green M,Apel A, Stapleton F. A Longitudinal study of trends in keratitis in Australia. Cornea. 2008;27:33-39.

21. Green M, Apel A, Stapleton F. Risk factors and causative organisms in microbial keratitis. Cornea. 2008;27:22-27.

22. Keijser S, Kurreeman FA, de Keizer RJ, et al. IL-10 promotor haplotypes associated with susceptibility to and severity of bacterial corneal ulcers. Exp Eye Res. 2009;88:1124-1128.

23. Upadhyay MP, Karmacharya PC, Koirala S, et al. The Bhaktapur eye study: ocular trauma and antibiotic prophylaxis for the prevention of corneal ulceration in Nepal. Br J Ophthalmol. 2001;85:388-392.

24. Erie JC, Nevitt MP, Hodge DO, Ballard DJ. Incidence of ulcerative keratitis in defined population from 1950 through 1988. Arch Ophthalmol. 1993;111:1665-1671.

25. Stapleton F, Keay L, Edwards K, Naduvilath T, Dart JK, Brian G, Holden BA. The incidence of contact lens-related microbial keratitis in Australia. Ophthalmol. 2008;115:1655-1662.

26. Liesegang TJ. Contact lens-related microbial keratitis: Part I: Epidemiology. Cornea. 1997;16:125-131.

27. Musa F, Tailor R, Gao A, Hutley E, Rauz S, Scott RA. Contact lensrelated microbial keratitis in deployed British military personnel. Br J Ophthalmol. 2010;94:988-993.

28. Moriyama AS, Hofling-Lima AL. Contact lens-associated microbial keratitis. Arq Bras Oftalmol. 2008;71:32-36.

29. Amer Awan M, Reeks G, Rahman MQ, Butcher I, Ramaesh K. The patterns of in vitro antimicrobial susceptibility and resistance of bacterial keratitis isolates in Glasgow, United Kingdom. Clin Exp Optom. 2010;93:354-359. 
30. Sueke H, Kaye S, Neal T, et al. Minimum inhibitory concentrations of standard and novel antimicrobials for isolates from bacterial keratitis. Invest Ophthalmol Vis Sci. 2010;51:2519-2524.

31. Al-Shakarchi FI. Initial therapy for suppurative microbial keratitis in Iraq. Br J Ophthalmol. 2007;91:1583-1587.

32. Al-Yousuf N. Microbial keratitis in Kingdom of Bahrain: clinical and microbiology study. Middle East Afr J Ophthalmol. 2009;16:3-7.

33. Shah R, Shah M, Khandekar R, Al-Raisi A. Contact lens induced corneal ulcer management in a tertiary eye unit in Oman - a descriptive study. Sultan Qaboos Univ Med J. 2008;8:283-290.

34. Capriotti JA, Pelletier JS, Shah M, Caivano DM, Turay P, Ritterband DC. The etiology of infectious corneal ulceration in Sierra Leone. Int Ophthalmol. 2010;30:637-640.

35. Ubani UA. Bacteriology of external ocular infections in Aba, South Eastern Nigeria. Clin Exp Optom. 2009;92:482-489.

36. Bharathi MJ, Ramakrishnan R, Meenakshi R, Kumar CS, Padmavathy S, Mittal S. Ulcerative keratitis associated with contact lens wear. Indian J Ophthalmol. 2007;55:64-67.

37. Bharathi MJ, Ramakrishnan R, Shivakumar C, Meenakshi R, Lionalraj D. Etiology and antibacterial susceptibility pattern of community-acquired bacterial ocular infections in a tertiary eye care hospital in south India. Indian J Ophthalmol. 2010;58:497-507.

38. Inoue N, Toshida H, Mamada N, Kogure N, Murakami A. Contact lens-induced infectious keratitis in Japan. Eye Contact Lens. 2007;33:65-69.

39. Yu DK, Ng AS, Lau WW, Wong CC, Chan CW. Recent pattern of contact lens-related keratitis in Hong Kong. Eye Contact Lens. 2007;33:284-287.

40. Zhang C, Liang Y, Deng S, Wang Z, Li R, Sun X. Distribution of bacterial keratitis and emerging resistance to antibiotics in China from 2001 to 2004. Clinl Ophthalmol. 2008;2:575-579.

41. Fong CF, Hu FR, Tseng CH, Wang IJ, Chen WL, Hou YC. Antibiotic susceptibility of bacterial isolates from bacterial keratitis cases in a university hospital in Taiwan. Am J Ophthalmol. 2007;144: 682-689.

42. Pandita A, Murphy C. Microbial keratitis in Waikato, New Zealand. Clin Exp Ophthalmol. 2011;39:393-397.

43. Edwards K, Keay L, Naduvilath T, Snibson G, Taylor H, Stapleton F. Characteristics of and risk factors for contact lens-related microbial keratitis in a tertiary referral hospital. Eye. 2009;23:153-160.
44. Stapleton F, Keay LJ, Sanfilippo PG, Katiyar S, Edwards KP, Naduvilath T. Relationship between climate, disease severity, and causative organism for contact lens-associated microbial keratitis in Australia. Am J Ophthalmol. 2007;144:690-698.

45. Hall RC, McKellar MJ. Bacterial keratitis in Christchurch, New Zealand, 1997-2001. Clin Exp Ophthalmol. 2004;32:478-481.

46. Sy A, Srinivasan M, Mascarenhas J, et al. Pseudomonas aeruginosa keratitis: outcomes and response to corticosteroid treatment. Invest Ophthalmol Vis Sci. 2012;53:267-272.

47. Mohammadpour M, Mohajernezhadfard Z, Khodabande A, Vahedi P. Antibiotic susceptibility patterns of Pseudomonas corneal ulcers in contact lens wearers. Middle East Afr J Ophthalmol. 2011;18:228-231.

48. McAllum PJ, McGhee CNJ. Prescribing trends in infectious keratitis: a survey of New Zealand ophthalmologists. Clin Experiment Ophthalmol. 2003;31:496-504.

49. Keay L, Edwards K, Naduvilath T, et al. Microbial keratitis: predisposing factors and morbidity. Ophthalmology. 2006;113:109-111.

50. O'Brien TP, Maguire MG, Fink NE, Alfonso E, McDonnell P; The Bacterial Keratitis Study Research Group. Efficacy of ofloxacin vs cefazolin and tobramycin in the therapy for bacterial keratitis. Arch Ophthalmol. 1995;113:1257-1265.

51. Khokhar S, Sindhu N, Mirdha BR. Comparison of topical 0.3\% ofloxacin to fortified tobramycin-cefazolin in the therapy of bacterial keratitis. Infection. 2000;28:149-152.

52. Chew FL, Soong TK, Shin HC, Samsudin A, Visvaraja S. Topical piperacillin/tazobactam for recalcitrant pseudomonas aeruginosa keratitis. J Ocular Pharmacol Ther. 2010;26:219-222.

53. McCormick C, Caballero A, Tang A, Balzli C, Song J, O'Callaghan R. Effectiveness of a new tobramycin $(0.3 \%)$ and dexamethasone $(0.05 \%)$ formulation in the treatment of experimental Pseudomonas keratitis. Curr Med Res Opin. 2008;24:1569-1575.

54. Oliveira AD, d'Azevedo PA, Francisco W. In vitro activity of fluoroquinolones against ocular bacterial isolates in São Paulo, Brazil. Cornea. 2007;26:194-198.

55. Ku JY, Kim P, Tong J, Wechsler A, McCluskey P. Multiresistant Pseudomonas keratitis. Clin Exp Ophthalmol. 2010;38:818-819.

56. Sueke H, Kaye SB, Neal T, Hall A, Tuft S, Parry CM. An in vitro investigation of synergy or antagonism between antimicrobial combinations against isolates from bacterial keratitis. Invest Ophthalmol Vis Sci. 2010;51:4151-4155.
Clinical Ophthalmology

\section{Publish your work in this journal}

Clinical Ophthalmology is an international, peer-reviewed journal covering all subspecialties within ophthalmology. Key topics include: Optometry; Visual science; Pharmacology and drug therapy in eye diseases; Basic Sciences; Primary and Secondary eye care; Patient Safety and Quality of Care Improvements. This journal is indexed on Submit your manuscript here: http://www.dovepress.com/clinical-ophthalmology-journal

\section{Dovepress}

PubMed Central and CAS, and is the official journal of The Society of Clinical Ophthalmology (SCO). The manuscript management system is completely online and includes a very quick and fair peer-review system, which is all easy to use. Visit http://www.dovepress.com/ testimonials.php to read real quotes from published authors. 